\title{
Ethical Aspects of Human Embryo Collections: A Historically Grounded Approach to the Blechschmidt Collection at the University of Göttingen
}

\author{
Michael Markert
}

Professur für Materialität des Wissens, Kunstgeschichtliches Seminar, Universität Göttingen, Göttingen, Germany

\section{Keywords}

Collection ethics - History of embryology · Human remains . Tissue collections

\begin{abstract}
Human body donation and tissue collections are nowadays grounded on a legal framework centered around the concept of informed consent in most countries. Comparable regulations did not exist prior to the second half of the 20th century, when several of the most important collections of human embryos were established. As a particularly prominent example, the Human Embryology Collection ("Blechschmidt Collection") at the Center of Anatomy, University Medical Center Göttingen, Germany, is described here with regard to how to approach a human specimen collection from the perspective of both collection ethics and the history of science. The methods and concepts used as well as the outcome in terms of historical and ethical knowledge will be discussed as a model for future projects of similar scope at other collection sites. It it also shown that general ethical recommendations published by museum and collection experts are of value only if they are related to profound knowledge about the history of the particular collection in focus.

(c) 2021 The Author(s)

Published by S. Karger AG, Basel
\end{abstract}

\section{Why Embryo Collections Matter}

When it comes to collecting prenatal specimens, today's legal, biomedical, and public ethical discourse focuses on embryonic tissue stored in highly regulated biobanks. However, in some areas, biomedical research is dependent upon more traditional collections of embryonic and fetal specimens, i.e., collections of whole embryos or macroscopic preparations stored in jars filled with alcohol or formalin as well as collections of microscopical slides prepared from such specimens. Not least due to the relative scarcity of this type of specimens, these collections are important witnesses and references for the history of human embryology, especially in the 20th century. Also, scientific, medical, and, last but not least, ethical arguments were established based on human embryo collections in those days just as much as today and influence ongoing debates in medicine and society on dealing with unborn human life. Particularly the uncovering of human remains in medical or anthropological collections, frequently forgotten and accompanied by weak documentation (or none at all), continues to shake society's trust in science ethics with striking regularity and leads to calls for action and reflection [Knoeff, 2015]. As "Embryos are the central actors in the origin stories that many modern, educated people tell themselves - our-
(C) 2021 The Author(s)

Published by S. Karger AG, Basel

This article is licensed under the Creative Commons Attribution 4.0 International License (CC BY) (http://www.karger.com/Services/ OpenAccessLicense). Usage, derivative works and distribution are permitted provided that proper credit is given to the author and the original publisher.
Michael Markert

Professur für Materialität des Wissens

Kunstgeschichtliches Seminar, Universität Göttingen

Friedländer Weg 2, DE-37085 Göttingen (Germany)

michael.markert@uni-goettingen.de 
selves - about who we are and how we came to be" [Morgan, 2009], remains of unborn humans are of particular relevance in a broad cultural discourse on the use of human bodies, on what constitutes a human being, and who may have interests in its remains.

Because of its sensitive and emotional connotations, a scientific collection of human embryos and fetuses may be in the spotlight anyway. However, one that was started in National Socialist Germany is even more of an ethical challenge. In Germany, where under National Socialist dictatorship between 1933 and 1945 terrible crimes against humanity were committed also by medical practitioners, occasional findings of collections of preserved human body parts, for example brains or skulls, call for a fast and comprehensive reappraisal of their history of acquisition, preparation, and usage. It may, therefore, be no surprise that a systematic investigation focussing on the concrete origins of all embryonic and fetal specimens of a historical collection had to be carried out on the Blechschmidt Collection which started in the early 1940s. The founder of this collection, the anatomist and embryologist Erich Blechschmidt (1904-1992), Head of the Anatomische Institut (Anatomical Institute) - now Zentrum Anatomie (Center for Anatomy) - at Göttingen from 1942 to 1973, had taken advantage of National Socialist violence, malpractices, and injustice in terms of "material for research and teaching" similar to almost every representative of his discipline in Germany up to 1945 [Hildebrandt, 2009a, b, c]. Without known ethical concerns or moral doubts Blechschmidt "used" more than 130 victims of Nazi Germany executed at Wolfenbüttel (Lower Saxony) at least for teaching from 1942 to 1944 [Ude-Koeller et al., 2012]. Against this backdrop of "ethical transgressions" [Hildebrandt, 2016], Blechschmidt's stocks of prenatal human specimens and tissues are of particular historical interest and prime candidates for research on the origins of individual specimens.

In this article, the next section will briefly describe the Blechschmidt collection and the starting point of the historical research project that was carried out from 2017 to 2019. It is followed by an overview of the project's practical steps as an example for the accounting of a historical medical collection of (prenatal) human remains because the methods and procedures applied may be new for many users and supervisors of medical collections. Then, the outcome of the 2-year investigation will be outlined to show its scope and the tight connectedness of its sources. Subsequently, the results will be discussed in relation to the discourse on the care and ethics of human remains in university collections. In a final discussion, some key

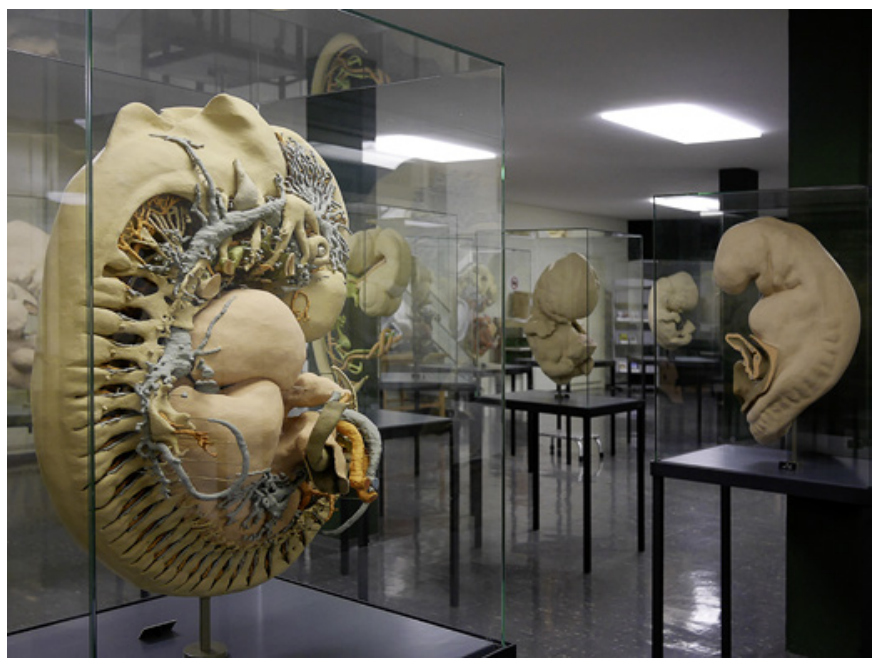

Fig. 1. View of the embryo model collection in the basement of the Zentrum Anatomie (Photo: Michael Markert).

aspects of this project will be addressed which may be helpful to cope with similar issues at other collection sites.

\section{The Collection}

The Blechschmidt Collection ("Humanembryologische Dokumentationssammlung Blechschmidt" - its original title in German) today is one of the most important embryo collections besides the Carnegie Collection [Noe, 2004], the Hubrecht Collection [Richardson and Narraway, 1999], and the Kyoto Collection [Yamaguchi and Yamada, 2018]. It consists of 2 major parts: The first part is a set of 61 large-scale models of human embryos or selected embryonic and fetal organs. They were constructed from the 1940s-1970s, each reaching a total height of 70-80 cm, and are housed up to this day in individual showcases in a dedicated exhibition hall measuring about 200 square meters (Fig. 1). Thirty-one of the models are based on Blechschmidt's own specimens and show complete embryos from 2.5 to $17.5 \mathrm{~mm}$ crownrump length. In terms of size and degree of detail, they are unsurpassed worldwide and are still in use in the teaching of medical students and students of healthcare professions with a training section on embryology [Männer, 2014]. The models are made of the two-component polymer called Leguval ${ }^{\circledR}$, newly developed in post-war Germany and produced at that time by Bayer, Leverkusen, Germany. For his models, Blechschmidt developed a modification of the wax plate reconstruction method 


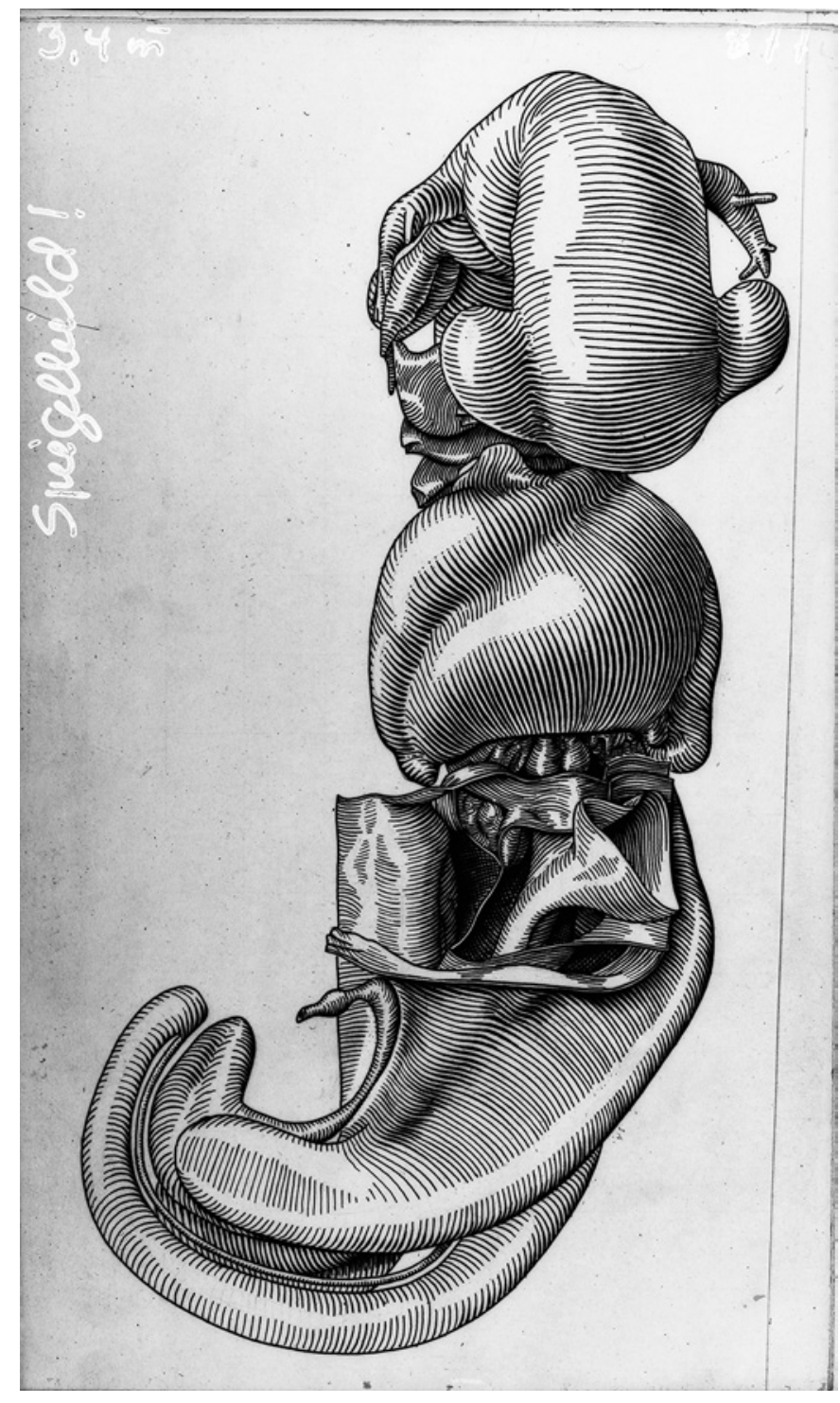

Fig. 2. Glass negative of a drawing of the specimen "April 09, 1954, 3.4" (Archive of the BlechschmidtCollection, GN_×9×12rot_0877) printed in "Die vorgeburtlichen Entwicklungsstadien des Menschen" in 1961 [Blechschmidt, 1961].

originally invented by the anatomist Gustav Born (18511900 ) at Breslau (today Wrocław, Poland) in the 1880s [Born, 1883, 1888]. Born's method uses enlarged drawings of whole series of histological slides transferred to wax plates, which were then mounted one upon another to build up physical models as an exact representation of the specimen from which the histological sections had been made [Hopwood, 1999, 2002, 2004]. Blechschmidt, on the other hand, used wax plates as negative forms and filled them with the polymer which allowed for larger,

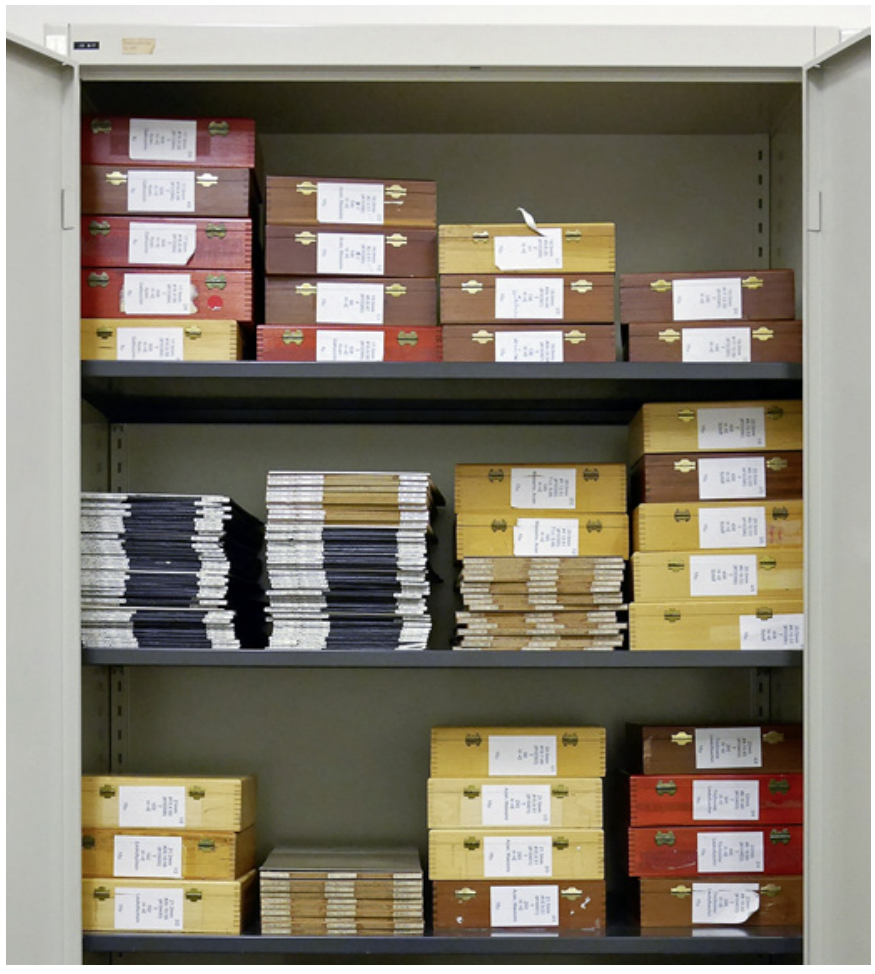

Fig. 3. View into 1 of 4 steel lockers containing serially sectioned embryos stored on trays (originally) and in wooden boxes (in later years) (Photo: Michael Markert).

more stable, and exceptionally detailed models [Blechschmidt, 1954; Markert, 2020]. Wax plate reconstruction in its many varieties [Gaunt and Gaunt, 1978] was the de facto standard for research on anatomical details in embryology up to the 1980s and has now been widely replaced by digital on-screen-three-dimensional reconstructions [de Bakker et al., 2016]. These days, renderings of digital imaging methods are part of publications on embryonic anatomy and development, but at that time authors like Blechschmidt published images of reconstruction models. Especially in his large and extensive monographs [Blechschmidt, 1961, 1963, 1973], detailed, high-quality drawings of models are shown (Fig. 2), whereas other Blechschmidt publications often feature photomicrographs of histological sections or schematic sketches, only. [For a complete list of Blechschmidts publications see Freeman, 2019].

The other major part of the collection are 115 human embryos and more than 300 parts of fetuses stored as microscopic slides (Fig. 3). About 30 series of these embryos and fetal parts were used for model construction, while most of the other specimens only rarely found their way 
Fig. 4. Index card (top left) from the 1950s describing the preparation protocol of the specimen "April 09, 1954, $3.4 \mathrm{~mm}$ " and a photomicrograph (bottom right) of the specimen before the laboratory procedure started. Black bars (added by the author of this article) block the personal details of the medical practitioner who provided the specimen (Archive of the Blechschmidt Collection, I 2).

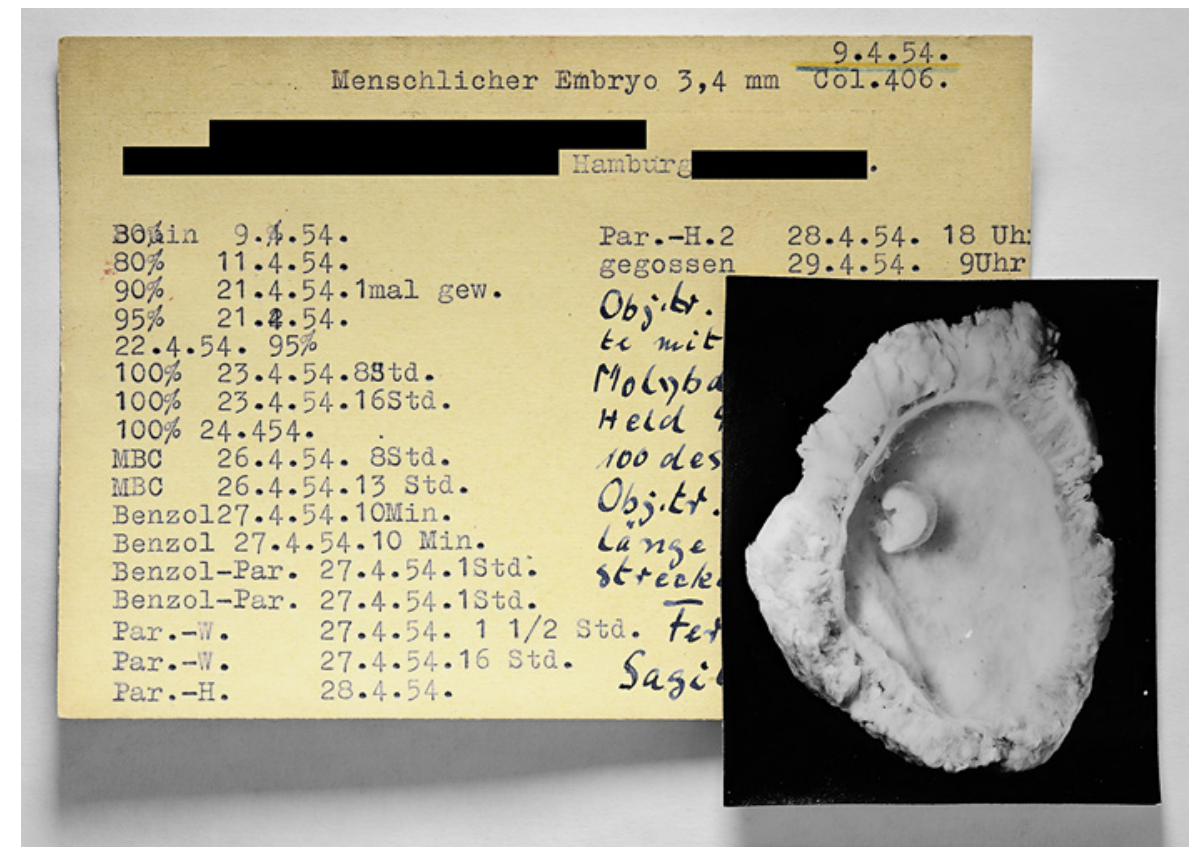

into models, publications, and other forms of presentation. The slide collection is accompanied by an electronic inventory in the form of an Excel chart containing core information on the individual specimens such as crown-rump length, date of preparation, chemicals used for fixation and preparation, diameter, and quantity of the glass slides. For only 75 of the more than 400 histological series the inventory contains information on the provenance of the specimens. This information is mostly very basic such as "Clinic for obstetrics and gynecology, Göttingen" or "Dr. [surname], Hannover" (Fig. 4). Furthermore, Blechschmidt gave no detailed information on his specimens in publications, and in most cases it is still not possible to trace back a particular specimen to an individual record in the collection. The lack of information in and on the Blechschmidt Collection even extends to the reconstruction models, as there are no accompanying texts in the exhibition hall: small labels of the models just state the length of the respective specimen and its estimated age of development in the form of, for example, " $10 \mathrm{~mm}$, middle of the 2 nd month".

\section{Project Outline}

The wide, and widely acknowledged, lack of information on the models, the histological slides, and on the specimens lead, quite understandably, to speculations about possible ethical misconduct concerning Blech- schmidt's specimen acquisition strategies, especially during 1942-1945. Drawing upon Blechschmidt's use of victims of Nazi executions, the core hypothesis was that Blechschmidt or his staff dissected pregnant women murdered in national socialist facilities to obtain embryos and fetuses [Ritter, 1989, 1991; Mildenberger, 2016a, b]. To address these speculations, every archival source available had to be used to develop a historical description as all-encompassing as possible which could serve as a base for a comprehensive evaluation of the collection in terms of science ethics. Therefore, a 2-year research project on the provenance of the specimens was funded by the Zentrale Kustodie (University Collection Management), Zentrum Anatomie, and Universitätsmedizin Göttingen (University Medical Center) in equal shares. From August 2017 to July 2019, the author of this paper reconstructed the history of acquisition, transport, preparation, sectioning, collection integration, usage, and publication of human embryos and fetuses processed at the Anatomisches Institut between 1942 and 1974. This was achieved by using hitherto undocumented but extensive archival records at the Zentrum Anatomie, by interviews with contemporary witnesses of the heydays of the collection, and finally by an extensive study of the publications of Blechschmidt and his followers, which aimed at finding data on the collection specimens used. Support came from an external advisory board that was staffed with experts on the history of embryology (Nick Hopwood, 
Cambridge, UK), ethics of anatomy in the national socialist era (Sabine Hildebrandt, Cambridge, MA, USA), medical ethics (Claudia Wiesemann, Göttingen, Germany), obstetrics and gynecology (Klaus Hermann Diedrich, Hamburg, Germany; Hermann Hepp, München, Germany), and legal implications (Sebastian Graf von Kielmansegg, Kiel, Germany).

\section{Project Workflow}

The work on the project was divided into 4 distinct phases: during the first 6 months, a voluminous and diverse but comprehensive stock of archival sources at the Zentrum Anatomie had to be examined. The sources and materials were partly gathered in preparation for the project by the staff of the Zentrum Anatomie, others were found by the author looking through old cabinets and drawers as he received permission to independently search for documents in all relevant rooms of the embryological division. The found folders, bundles of papers, and portfolios contained hundreds of letters from delivering institutions and individual persons as well as carbon copies of letters Blechschmidt had sent to clinics and physicians. In addition, the historical correspondence gave a detailed insight into the routine business at the Anatomische Institut in post-war Germany and especially into the planning and practice of Blechschmidt's extensive modeling programme. One of the most striking findings was a collection of about 8,000 glass negatives and glass slides in a wall cabinet in the exhibition hall of the reconstruction models. Only one current member of the Zentrum Anatomie could remember the existence of these images, which show specimens before preparation, histologically stained slides, and reconstruction models (Fig. 5); some of these were unknown and are not part of the collection today. Furthermore, several hundred nonstained specimens of human embryos and fetuses in different storage sites at the Zentrum Anatomie - a number of them were part of a former teaching collection - could be reconnected to the legacy of Erich Blechschmidt.

The exploration of sources and materials was complemented by interviews with contemporary witnesses of the Blechschmidt era and that of his successor, the latter especially to understand changes of the institutional framework that may have affected the collection and its storage sites. Offprints of Blechschmidt's articles and archived doctoral theses mentioning specimens gave an impression of the usage of collected embryos and fetuses in research. Also, sources from federal and university archives

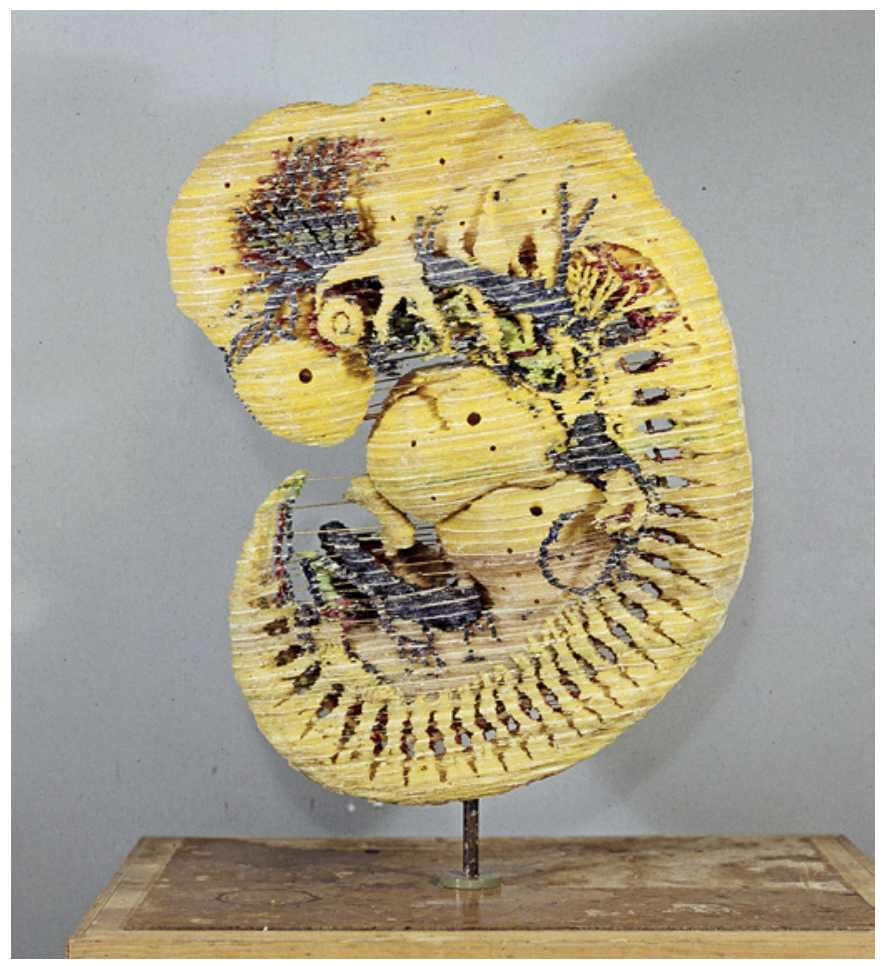

Fig. 5. Reproduction of a glass negative showing a reconstruction model related to specimen "October 26, 1945, $7.5 \mathrm{~mm}$ " during the building process, i.e., immediately following the removal of the wax, which had kept all plastic elements in each enlarged section in place during the assembly of the block of sections. (Archive of the Blechschmidt Collection, GN_×9×12_4765).

related to Blechschmidt and his works especially during the Nazi era were consulted (Federal Archive Berlin-Lichterfelde, Military Archives Freiburg, University archives of Freiburg, Göttingen, Wien, Würzburg. No relevant sources were found in the City Archive Göttingen and State Archive of Lower Saxony).

After this exploratory phase, a second 6-month phase was devoted to data gathering on all the new object and source stocks related to the Blechschmidt Collection. All documents of specimens which could be tracked using Blechschmidt's correspondence were registered with the inclusion of information on suspected specimen number, date, sender/sending institution, and city/state. In parallel, 4 student assistants digitized the glass negatives and slides, indexed wet-prepared specimens, transcribed handwritten image inventories, and relocated as well as repacked collection items. Finally, 2 of the student assistants revised the old slide collection inventory and made several hundred corrections to the 430 datasets on indi- 
Fig. 6. Sample of the revised collection inventory. Corrections are marked in red.

\begin{tabular}{|c|c|c|c|c|c|c|c|c|c|}
\hline Name Objekt & $\begin{array}{r}\text { ssum } \\
\mathrm{m}\end{array}$ & 아 & $\begin{array}{l}\text { Anzahy } \\
\text { ot }\end{array}$ & Zust Serie & Bemerk. & Sammig. & gepruit & $\begin{array}{l}\text { Stand } \\
\text { ort }\end{array}$ & Kommentar \\
\hline 20.10 .1958 Exa. & 18 & $1-136$ & 136 & & & $\begin{array}{l}\text { Blechschmidt USA } \\
\text { goliohen }\end{array}$ & Ja & E-B.1 & \\
\hline 20.10 .1958 Eyo. & 21,2 & 1.192 & 192 & & & $\begin{array}{l}\text { Blechschmidt USA } \\
\text { goliohen }\end{array}$ & Ja & E-8.3 & \\
\hline 02.12 .1959 Era & 21,5 & $1 \cdot 10$ & 10 & & $\begin{array}{l}\text { unvollstandig.nur } \\
10 \mathrm{OT}\end{array}$ & Blechschmidt Qs & Ja & E-8.3 & \\
\hline 22.12 .1958 Chocion & 7,8 & 1.25 & 25 & & & Becthoschoid ob. & Ja & E.A.1 & Auf der Obersichstitafel ist eine Fotografie. \\
\hline 22.12.1958 Dotsorsack & 7.8 & 1.33 & 33 & & & Blochachmidt Go. & Ja & U.8.5 & \\
\hline 22.12 .1958 Exe. & 7,8 & 1.25 & 25 & & & $\begin{array}{l}\text { Blochschmidt USA } \\
\text { goliohen }\end{array}$ & & & \\
\hline 08.01.1959 Kopf & 45 & $1-805$ & & $\begin{array}{l}\text { Die } \\
\text { Deckglsschen } \\
\text { haben sich beil } \\
\text { ionisen OT gollost }\end{array}$ & $\begin{array}{l}\text { Zahireiche } \\
\text { Schrite fehlen } \\
\text { (siehe Obbrasichs) } \\
\text { e unvollstandig }\end{array}$ & Blochschmidt Go. & Ja & U.8.6 & 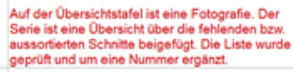 \\
\hline 1401.1969 Exo. & 15 & $\begin{array}{r}1.236 \\
237-496\end{array}$ & 495 & & & Blechschmidt Go. & Ja & E.A.4 & \\
\hline 19.01.1969 ExO. & 13 & 1.337 & 337 & & & $\begin{array}{l}\text { Plochschomidt USA } \\
\text { goliohon }\end{array}$ & Ja & E.A.3 & \\
\hline & 57.1 & 1.941 & 941 & $\begin{array}{l}\text { OT } 878 \\
\text { zertochen }\end{array}$ & & & & & \\
\hline 20.02 .1959 Bein, 8 & 27.2 & 1.27 & 27 & & & Bechschmide os & Ja & U.c-1 & \\
\hline 20.02.1959 Bein, te. & 27.2 & 1.62 & 62 & & & Blechschonidt C6. & Ja & U.c.-1 & \\
\hline & & & & & $\begin{array}{l}\text { Not } 45,46,69,75- \\
87 \text { und } 93-98\end{array}$ & & & & Unter der Obersichtstafel liegt eine Obersicht \\
\hline
\end{tabular}

vidual series of microscopic slides, which are based on 290 individual embryos and fetuses or parts thereof, respectively (Fig. 6).

In a third phase, all data pools related to the collection were brought together to reconstruct density, distribution, and scope of the acquisition network with Blechschmidt in Göttingen at the centre. This was accompanied by an analysis primarily using image metadata which focused on distinguishable and unique individual specimens processed in the institute but not necessarily integrated into the collection as physical items.

During the final months of the project, the results of all analytical strategies were combined for a detailed historical account of everyday practices at the Göttingen Anatomische Institut related to the embryo and fetus collection(s). The outcome was written down in an elaborate project report addressing all relevant aspects from accounting for senders at medical institutions to specimen preparation to model usage in research and teaching. The German report [Markert, 2019b] containing full references to the sources and documents used can be obtained on request from the author and is planned for online publication with a summary already available [Markert, 2019a]. All documents at the Zentrum Anatomie related to the Blechschmidt Collection are accessible on request to the head of the Abteilung für Anatomie und Embryologie (Department of Anatomy and Embryology).

\section{Research Outcome}

Of the 290 individual embryos and fetuses, which are still present in the Blechschmidt Collection of histological stained specimens at Göttingen, 175 are provided with information on the sending institution or person. For ob- taining a clear proof of origin, the location data was linked to incoming letters and carbon copies of Blechschmidt's replies, but this proved to be possible for 18 specimens, only. This weak documentation of specimen extraction and delivery is in harsh contrast to common scientific practice at least today, but also in the heyday of embryo collections as, for example, in the famous Carnegie Embryo Collection, Washington (D.C.) [Morgan, 2004; Hopwood, 2007]. Among the 18 assignable specimens 5 belong to the 9 embryos which Blechschmidt used from his collection for his large total reconstruction models. This demonstrates that some of the specimens essential for Blechschmidt's research and teaching programme can be connected, indeed, to events in clinics and surgeries in post-war Germany. In fact, about $94 \%$ of all histologically processed embryos were added to the collection after the end of the Second World War up to 1969. The most prominent exception is a specimen with a CRL of $29 \mathrm{~mm}$ which Blechschmidt had brought to Göttingen from his earlier affiliation with Freiburg University, Freiburg, Germany, and which had been obtained during gynecological surgery in 1939. (It should be mentioned that there is another much smaller embryo collection founded by Blechschmid's successor as head of the embryological division Gerd Steding (1936-2011), that was elaborated up to the 1990s but has no noticeable connection to the Blechschmidt Collection or acquisition network and therefore was not an object of study within the project.)

Although case histories or details on the applied medical procedures are available for only very few of the actual collection items, the analysis of Blechschmidt's archived correspondence reveals the origin of specimens to have been anything from spontaneous abortions and stillbirths to induced abortions, ectopic pregnancies, total uterus extirpations, and autopsies which often were carried out in the region of Niedersachsen (Lower Saxony) 


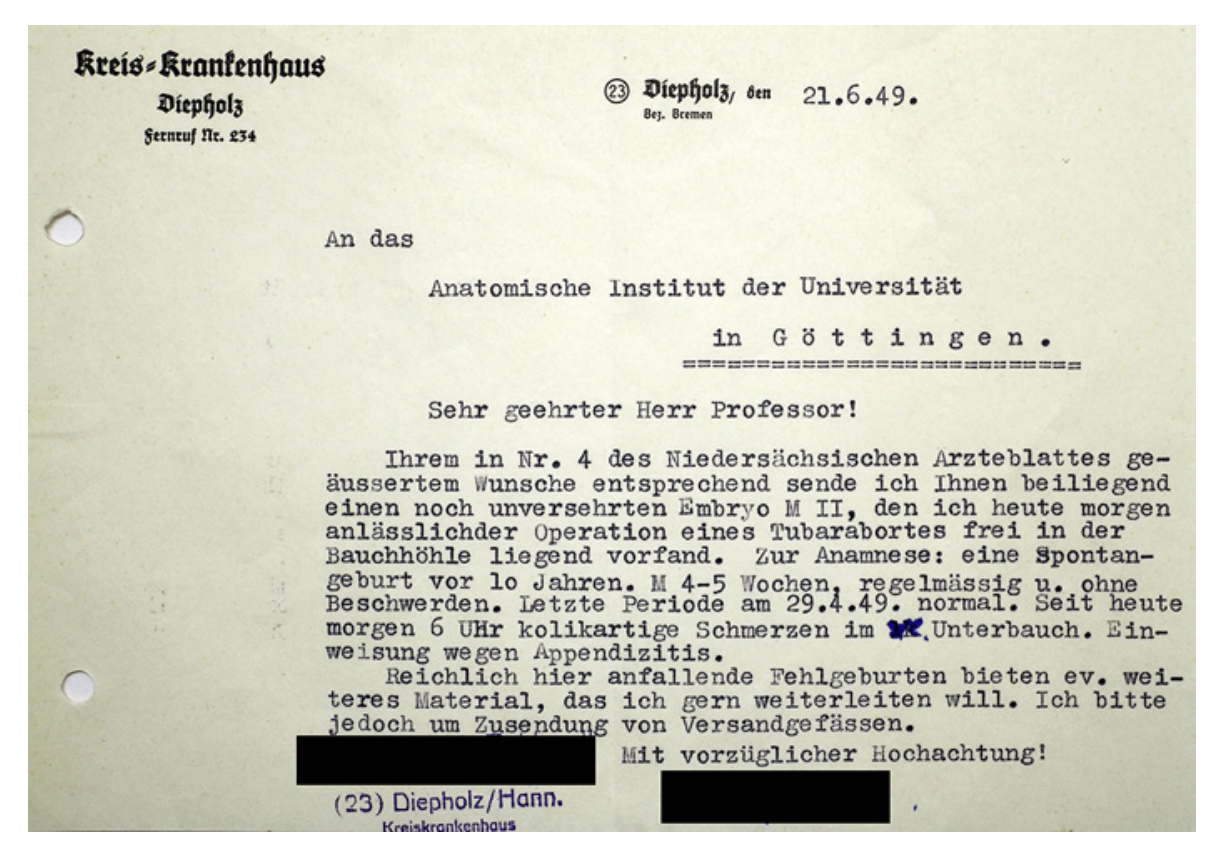

Fig. 7. Letter from a sender from Lower Saxony mentioning an ectopic pregnancy as the origin of the specimen, "June 22, 1949, $17.5 \mathrm{~mm}$ ", of which 5 total reconstruction models had been made (Archive of the Blechschmidt Collection, E 1). Following German law, personal rights have to be maintained for 10 years after death using anonymization. As there is no personal information on most of the several hundred senders, the names were anonymized for the purpose of this publication.
(Fig. 7). A smaller number of submissions were from other regions of Germany as well as from European (especially Finland, see below) and non-European countries, although the latter left no discernible traces in the collection as it stands today. Blechschmidt's cooperation partners sent many more specimens to Göttingen than were included in the collection, and it can be assumed that there were several thousands in total, arriving during his 3 decades of collecting activities, while at least 900 individuals can be identified using historical documents and images.

As part of his collection strategy, Blechschmidt approached future cooperation partners at gynecological clinics and local surgeries using personal letters or calls for cooperation in specialist journals [Anonymous $\mathrm{Au}-$ thor 1949; 1957]. He also addressed his students in courses and classes or made use of existing contacts within his family, with friends and (professional) acquaintances. In the archival material a total of 287 individuals and institutions can be distinguished of whom 179 took part in Blechschmidt's collection programme, some of them as reliable senders for many years. However, the most important source of specimens from 1944 up to Blechschmidt's retirement in 1973 is largely undocumented: the Frauenklinik (Clinic for obstetrics and gynecology) at Göttingen University, from where specimens of potential interest were picked up by the staff of the embryological department following a direct telephone call to Blechschmidt's office or laboratory. Most other cooperation

Ethical Aspects of Human Embryo

Collections partners sent the specimens to Göttingen by applying a standardized protocol which was provided by Blechschmidt and used glacial acetic acid and picric acid as fixative solutions.

In the archival files there are no indications of delivery of embryos and fetuses following procedures resulting from human rights violations in Nazi institutions neither are there any traces of an active cover-up of such origins. However, there are several ethical challenges which might be relevant for the future use of the collection and, in particular, for the public presentation of the unique reconstruction models:

Firstly, there might still be fetal specimens in today's collection that were obtained from forced abortions during the Nazi era up to 1945 because Blechschmidt received fetuses from clinics that carried out forced sterilizations and forced abortions during that time (Fig. 8). Although there are not many histologically stained specimens from the period between 1942 and 1945 in today's collection, Blechschmidt and his technical staff always kept specimens unprepared as a supply for research and teaching. Therefore, fetuses from forced abortions might have been integrated into the histological stains collection years or decades after the war.

Secondly, according to gynecological literature, ectopic pregnancies correlate with gonorrhea, which occurred frequently in Germany as an aftermath of the Second World War [Heberer, 1948; Lehmann, 1951; Schramm, 1952]. As there was a significantly increased number of 


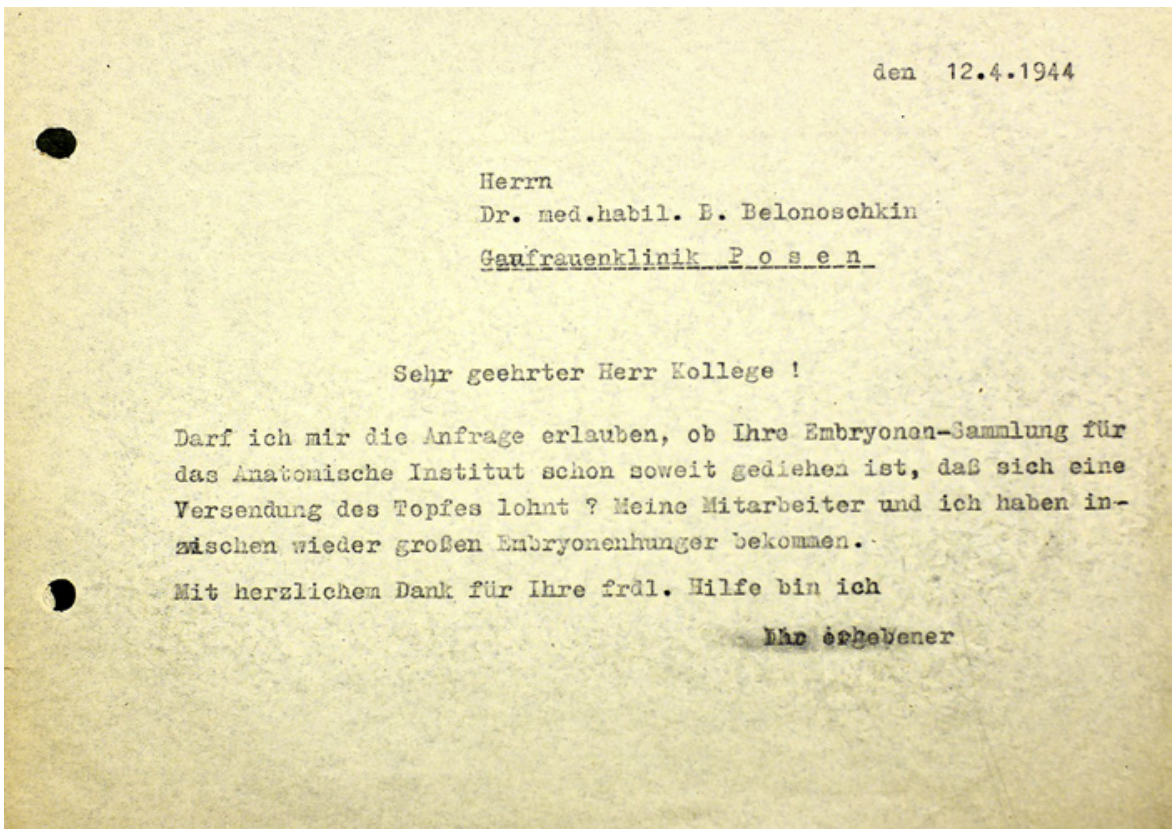

Fig. 8. Letter from Blechschmidt asking Boris Belonoschkin, Head of the Clinic for Obstetrics and Gynecology Posen (Poznan) in April 1944, as to whether he could send another lot of specimens as he and his staff had "big hunger for embryos again" (Archive of the Blechschmidt Collection, E 1). ectopic pregnancies and collection specimens from 1948 to 1954 - nearly $48 \%$ of all series of histological stained embryos and fetuses were dated accordingly - these must be treated as indirect consequences of the war.

Thirdly, according to customs documents found at the institute as well as a contemporary witness and doctoral student of Blechschmidt (pers. comm. to the author, the interviewee was anonymized to maintain his personal rights. Contact can be provided on request), several specimens were sent to Göttingen from a clinic for obstetrics and gynecology in Helsinki during the 1960s. The witness claims that these specimens were obtained following legal induced abortions carried out as cesarean sections instead of the usual curettages as a kind of "educational surgery" for prospective gynecologists. He further explained that the patients often were members of the Saami community. Therefore, the unnecessary and potentially harmful treatments could be rated as structural violence against an ethnic minority. Information about these events was shared with the Saami Council (Email correspondence with Áile Jávo, Secretary General of the Saami Council, on April, 27 2018), but as all the respective specimens appear to have been destroyed in the course of electron microscopical analysis, no repatriation process was initiated.

In addition to these issues which refer to specific historical events and conditions there is a fourth ethical issue of a more general nature: as far as can be deduced from the correspondence between Blechschmidt and the send- ers, there was no informed consent for the storage and use of a specimen in any known case. Moreover, it is unlikely that the patients knew about a transfer of their tissue to the Anatomische Institut in Göttingen with the intention of integration into the institute's collection. However, informed consent for the use of tissue removed during medical procedures in research and teaching was neither necessary nor customary during the period in question. Also, the concept of informed consent itself has developed historically and has been subjected to ethical challenges [e.g., Nijhawan et al., 2013].

\section{General Ethical Considerations}

Coincidentally, during the final phase of the project, guidelines for the use of historical collections of embryonic and fetal specimens based on ethical considerations were published by Fourniquet et al. [2019]. These guidelines mainly consider the question as to whether informed consent was provided by the donors of specimens or not. In the event that consent cannot be verified - as is the case with the Blechschmidt Collection - they recommend storage and use in research and teaching if (1) there is a justified demand and (2) the usage is non-commercial. Additionally, utilization of such specimens for digital reproduction and genetic investigation should not be allowed as these technologies are still ethically challenging even if informed consent had been given. The recommen- 
dations by Fourniquet et al. [2019] may fit most collections which stem from the days before the introduction of rulings on informed consent in Germany and elsewhere. However, historical specimens which are linked to other and more extreme violations of today's principles of medical ethics, i.e., when obtained in the context of human rights violations, are not addressed. However, as even "Consulting Evil" - the title of a commentary [Caplan, 2019] on the use of drawings linked to victims of Nazi executions in Eduard Pernkopf s well-known anatomical atlas [Pernkopf, 1937] - is highly debated, such historical contexts of specimens should be considered separately.

Presently available guidelines for the care of human remains in historical medical collections in Germany are the "Stuttgarter Empfehlungen" (Stuttgart Recommendations) of the Bundesärztekammer (German Medical Association) which were released in 2003 [Bundesärztekammer, 2003]. These recommendations explicitly focus on human remains obtained from human rights violations during the Nazi era or of unknown provenance especially when there is the possibility that they were incorporated in a collection between 1933 and 1945. The authors of the Stuttgarter Empfehlungen, having distinctly different professional backgrounds such as medicine, law, ethics, and theology, plead for cremation and burial of such collection items if there are no sound, superior reasons supporting a particularly high relevance for research, teaching, or public education. Such arguments then would have to be documented for every single collection item thought to merit being preserved. Irrespective of the existence of such items, their decommissioning or documentation of the reasons for keeping them, the Stuttgarter Empfehlungen recommend the establishment of a place for symbolic remembrance of the people whose remains were integrated into the respective collection. If such a collection is open to the public, the history of the respective collection as well as related ethical challenges - if there are any - should be addressed in detail on-site accessible to all visitors.

\section{Recommendations for the Handling of the Blechschmidt Collection}

If these ethical principles were to be applied to the Blechschmidt Collection, a first step would address the need to comprehensively inform about the history of the collection and the ethical considerations. The project's results should be included in the existing websites and in the model exhibition itself. In the exhibition hall, which is open to the public, a place for symbolic remembrance of the countless female patients involved involuntarily should be established. An on-site information chart should (1) address Blechschmidt's collecting activity, (2) the fact that informed consent was generally missing, and (3) the ethical issues mentioned above concerning specimen retrieval.

Secondly, future users of the collection should refer to the provenance research project and its results in publications and reports or indeed during guided tours on embryology in the exhibition hall. Access to databases which contain image data from the Blechschmidt Collection should require permission from the collection manager. As there is no hard evidence in the context of human rights violations regarding individual series of slides, following the Stuttgarter Empfehlungen, storage and use may be justified as far as the potential human rights violations mentioned above are considered. However, usage itself could be an ethical challenge from the perspective of the guidelines by Fourniquet et al. [2019] as some of the stained embryos have recently been the basis for virtual three-dimensional reconstructions [Miyazaki et al., 2018; Kruepunga et al., 2020a, b] and these are thus digital reproductions of specimens without informed consent. For future use, a weighting of competing interests following consultation of the Stuttgarter Empfehlungen should take place with the hindsight of restricting access to digital images and virtual models. In particular, if images of specimens and digital derivatives are intended to be published, at least the specific history of the Blechschmidt Collection and the absence of informed consent should be mentioned.

Thirdly, specimens without a convincing relevance for research and teaching should be sorted out and buried as may seem to be appropriate especially in the case of approximately 100 to 200 stored but non-processed specimens from the Blechschmidt era (see section Project Workflow). Most of these resulted from miscarriages and stillbirths from the 1940s-1970s, had no accompanying data, and presumably had been reserved for later preparations. However, a separate, detailed investigation addressing each and every of these specimens in the light of the weighting process mentioned above needs to be carried out before final decisions can be made.

The implementation of these recommendations at the Blechschmidt Collection is still pending as of November 2020. However, the curators of the collection acknowledged them gratefully in their entirety and will take every necessary step to implement them as soon as possible in 
particular ensuring that further research articles will not be published without referring to the published project summary or without mentioning the ethical issues detailed herein (pers. comm. to the author, Email correspondence with Christoph Viebahn on September, 9 2020).

\section{Transferable Key Aspects of the Project}

Based on pressing concerns related to ethical transgressions during the Nazi era, stakeholders from Göttingen University funded an independent researcher who conducted a comprehensive historical as well as ethical analysis of an academic collection of human embryo and fetus tissue. With its objective and scope, the 2 -year project was the first of its kind. As collection history and ethics are of increasing relevance in many countries and contexts, several aspects of the project may be of interest to decision-makers and researchers at other collection sites. Although there are specific ethical concerns related to medical collections in Germany because of their history in the 20th century, some of the more transferable characteristics of the project at Göttingen may be the following: Firstly, a person with a degree in the history of science and with experience in archival work, specimen collections, and collection history but none in embryology or laboratory work realized the project. This may seem counter-intuitive but had the advantage of a fresh and unobstructed view on collection stocks as well as document piles of unknown origin and content. Secondly, the person carrying out the project should be autonomous in his or her methods, workflow, and scope of interpretation. Ideally which was the case in Göttingen - she or he should not be an employee at the institute under scrutiny but under contract at a "neutral" institution like the university collection management to avoid any conflicts of interest. Thirdly, it is of paramount importance that the institution housing the respective collection gives full access to all rooms, shelves, documents, and objects with the slightest possibility of being of any relevance, because the significance may become obvious only during the work on the project. Fourthly, the person carrying out the project should be aware - at an early stage of the project - of the discourse on collection ethics, applicable ethical standards, and their possible impact on the further storage and usage of collection items depending on the scope of ethically relevant historiographic conclusions. Fifthly, the comprehensive in-

spection of archival sources on the history of an institution and its collections will lead to historical insights that otherwise would not have been available. This could be of direct benefit also for embryological research.

In conclusion, this case study shows that ethical considerations are specific to the historical and cultural conditions of a collection and cannot be transferred in all detail to other sites and contexts. Therefore, generic ethical rules like those of Fourniquet et al. [2019] or the Stuttgarter Empfehlungen are of limited use only. They must be refined using arguments from research on the history of the particular collection in focus to be reasonable and applicable.

\section{Acknowledgement}

I would like to thank the Zentrale Kustodie, the Abteilung Anatomie und Embryologie of the Zentrum Anatomie, as well as the Institut für Ethik und Geschichte der Medizin for the dedicated support of the research project and during the publication process.

\section{Conflict of Interest Statement}

The project was funded by the Zentrale Kustodie (University Collection Management), the Zentrum Anatomie (Center of Anatomy), and the Universitätsmedizin Göttingen (University Medical Center) at equal parts with the author employed at the Zentrale Kustodie.

\section{Funding Sources}

See Conflict of Interest Statement. While writing the manuscript the author was employed at the Institut für Ethik und Geschichte der Medizin of the Universitätsmedizin Göttingen.

References

Cells Tissues Organs 2020;209:189-199 DOI: $10.1159 / 000513176$
Anonymous Author. Operative Embryonen der ersten Entwicklungsmonate. Niedersächsisches Ärztebl. 1949;3:106.

Anonymous Author. Embryonen für das Anatomische Institut der Univ. Göttingen. Zentralblatt Für Gynäkol. 1957;79:1852.

Blechschmidt E. Rekonstruktionsverfahren mit Verwendung von Kunststoffen. Ein Verfahren zur Ermittlung und Demonstration von Entwicklungsbewegungen. Z Anat Entwickl Gesch. 1954;118(2):170-4.

Blechschmidt E. Die vorgeburtlichen Entwicklungsstadien des Menschen. Basel: Karger; 1961.

Blechschmidt E. Der menschliche Embryo. Stuttgart: Schattauer-Verlag; 1963. 
Blechschmidt E. Die pränatalen Organsysteme des Menschen. Stuttgart: Hippokrates; 1973.

Born G. Die Plattenmodelliermethode. Archiv f. mikrosk. Anatomie. 1883;22(1):584-99.

Born G. Noch einmal die Plattenmodelliermethode. Z Für Wiss Mikrosk. 1888;5:43355.

Bundesärztekammer . Mitteilungen: Empfehlungen zum Umgang mit Präparaten aus menschlichem Gewebe in Sammlungen, Museen und öffentlichen Räumen. Dtsch Ärztebl. 2003;100:A1960-A1965.

Caplan A. Commentary: Consulting Evil. Surgery. 2019;165(5):870.

de Bakker BS, de Jong KH, Hagoort J, de Bree K, Besselink CT, de Kanter FE, et al. An interactive three-dimensional digital atlas and quantitative database of human development. Science. 2016;354(6315).

Freeman B . Bibliography of Articles, Films \& Books by Erich Blechschmidt. 2019; available at http://docplayer.org/312559-Bibliography-erich-blechschmidt-students-followerscompiled-by-b-freeman-unsw.html

Fourniquet SE, Beiter KJ, Mussell JC. Ethical rationales and guidelines for the Continued use of archival collections of embryonic and fetal specimens. Anat Sci Educ. 2019;12(4):40716.

Gaunt PN, Gaunt WA. Three dimensional reconstruction in Biology. Kent: Pitman Medical; 1978.

Heberer H. Über Extrauteringraviditäten.. Geburtshilfe Frauenheilkd. 1948;8:397-400.

Hildebrandt S. Anatomy in the Third Reich: An outline, part 1. National Socialist politics, anatomical institutions, and anatomists. Clin Anat. 2009a;22(8):883-93.

Hildebrandt S. Anatomy in the Third Reich: An outline, part 2. Bodies for anatomy and related medical disciplines. Clin Anat. 2009b; 22(8):894-905.

Hildebrandt S. Anatomy in the Third Reich: an outline, part 3. The science and ethics of anatomy in National Socialist Germany and postwar consequences. Clin Anat. 2009c;22(8) 906-15.

Hildebrandt S. The anatomy of murder. Ethical transgressions and anatomical science during the Third Reich. New York: Berghahn Books; 2016.

Hopwood N. "Giving body" to embryos. Modeling, mechanism, and the microtome in late nineteenth-century anatomy. Isis. 1999;90: $462-96$.
Hopwood N. Embryos in wax. Models from the Ziegler studio. Cambridge: Cambridge University Press; 2002.

Hopwood N. Plastic publishing in embryology. In: Hopwood $\mathrm{N}$, de Chadarevian $\mathrm{S}$, editors. Models Third Dimens. Sci. Stanford: Stanford University Press; 2004. p. 170-206.

Hopwood N. A history of normal plates, tables and stages in vertebrate embryology. Int $\mathrm{J}$ Dev Biol. 2007;51(1):1-26.

Knoeff R. Ball Pool Anatomy: On the Public Veneration of Anatomical Relics. In: Knoeff $\mathrm{R}$, Zwijnenberg R, editors. Fate Anat Collect. 2015;279-91.

Kruepunga N, Hikspoors JPJM, Hülsman CJM, Mommen GMC, Köhler SE, Lamers WH, et al. Development of extrinsic innervation in the abdominal intestines of human embryos. J Anat. 2020a;237(4):655-671. https://doi. org/10.1111/joa.13230.

Kruepunga N, Hikspoors JPJM, Hülsman CJM, Mommen GMC, Köhler SE, Lamers WH. Extrinsic innervation of the pelvic organs in the lesser pelvis of human embryos. J Anat. 2020b;237(4):672-688.

Lehmann W. Zur Diagnose und Therapie der Extrauteringravidität. Med Klin. 1951:612-6.

Männer J. Die Humanembryologische Dokumentationssammung Blechschmidt. Eine modellbasierte Gesamtschau auf einen dynamischen Formbildungsprozess. In: Ludwig D, Weber C, Zauzig O, editors. Materielle Modell Objektgeschichten. Aus Wiss Prax. Paderborn: Wilhelm Fink; 2014. p. 33-9.

Markert M. Die „Humanembryologische Dokumentationssammlung Blechschmidt": Geschichte einer sensiblen Sammlung, 19391973. Ergebnisse und Empfehlungen des Provenienzforschungsprojektes. Version 1.0 . 2019a.

Markert M. Abschlussbericht. „Die „Humanembryologische Dokumentationssammlung Blechschmidt". Geschichte einer sensiblen Sammlung, 1939-1973 Göttingen; 2019b. [unpublished].

Markert M. Modellierte Individualentwicklung. Humanembryologische Praktiken an der Universität Göttingen in der zweiten Hälfte des 20. Jahrhunderts. NTM. 2020;28:481517.
Mildenberger FG. Anatomist, Anti-Abortionist, Anti-Darwinian: The three lives of Erich Blechschmidt (1904-1992). Medizinhist J. 2016a;51:246-79.

Mildenberger FG. Anmerkungen zu Blechschmidt. Osteopathische Medizin. 2016b; 17(1):31-2

Miyazaki R, Makishima H, Männer J, Sydow HG Uwabe C, Takakuwa T, et al . Blechschmidt Collection: Revisiting specimens from a historical collection of serially sectioned human embryos and fetuses using modern imaging techniques. Congenit Anom (Kyoto). 2018, 58(5):152-7.

Morgan LM. A social biography of Carnegie embryo no. 836. Anat Rec B New Anat. 2004; 276(1):3-7.

Morgan LM. Icons of life. A cultural history of human embryos. Berkeley, Los Angeles, London: University of California Press; 2009.

Nijhawan LP, Janodia MD, Muddukrishna BS, Bhat KM, Bairy KL, Udupa N, et al . Informed consent: Issues and challenges. J Adv Pharm Technol Res. 2013;4(3):134-40.

Noe A. The human embryo collection. In: Maienschein J, Glitz M, Allen GE, editors. Centen. Hist. Carnegie Inst. Wash. Vol. V Dep. Embryol. Cambridge: Cambridge University Press; 2004. p. 21-61.

Pernkopf E Topographische Anatomie des Menschen, 1-7. Berlin: Urban \& Schwarzenberg; 1937.

Richardson MK, Narraway J. A treasure house of comparative embryology. Int J Dev Biol. 1999; 43(7):591-602.

Ritter B. Werkstoff Embryo. Konkret. 1989:8891.

Ritter B. Werkstoff Embryo. Zur Geschichte der Embryologie und Gynäkologie. Frauen gegen den $\$ 218$ - Bundesweite Koordination Vorsicht Lebensschützer! Die Macht der organisierten Abtreibungsgegner. Hamburg: Konkret-Literatur-Verl; 1991. p. 118-25.

Schramm G. Diagnose und Therapie der verschleppten Tubargravidität. Münch Med Wochenschr. 1952:963-70.

Ude-Koeller S, Knauer W, Viebahn C. Anatomical practice at Göttingen University since the Age of Enlightenment and the fate of victims from Wolfenbüttel prison under Nazi rule. Ann Anat. 2012;194:304-13.

Yamaguchi Y, Yamada S. The Kyoto Collection of Human Embryos and Fetuses: history and recent advancements in modern methods. Cells Tissues Organs. 2018;205:314-9.
Ethical Aspects of Human Embryo Collections
Cells Tissues Organs 2020;209:189-199

DOI: $10.1159 / 000513176$ 